\title{
The Blood-Retinal Barrier in Angioid Streaks
}

\author{
R. BROWN ${ }^{1}$ and M. F. RAINES ${ }^{2}$ \\ Manchester
}

\section{Summary}

The blood retinal barrier was investigated in a group of patients with angioid streaks and pseudoxanthoma elasticum, using the technique of vitreous fluorophotometry. Angioid streaks are breaks in the elastic layer of Bruch's membrane with atrophy of the adjacent pigment epithelium. The retinal pigment epithelial cells and their intercellular junctions form part of the blood retinal barrier.

In this study it was found that despite the presence of angioid streaks and extensive areas of pigment epithelial atrophy the blood retinal barrier was intact. In contrast, when disciform degeneration had occurred the blood retinal barrier was abnormal.

It is proposed that vitreous fluorophotometry could be used to identify those patients developing disciform degeneration at an early and therefore potentially treatable stage.

Angioid streaks are ophthalmoscopically visible red-brown streaks that radiate from the peripapillary area of the fundus. They are often associated with pseudoxanthoma elasticum, a generalised disturbance of elastic tissue throughout the body. ${ }^{1.2}$

The important complications of angioid streaks are subretinal neovascularisation and choroidal haemorrhage, either of which may present clinically with disturbance or loss of vision. ${ }^{3-5}$

Angioid streaks represent breaks in the elastic layer of Bruch's membrane accompanied by varying degrees of disturbance and atrophy of the overlying retinal pigment epithelium."

The retinal pigment epithelial cells and their junctions form part of the blood-retinal barrier (BRB). ${ }^{7,8}$ When this barrier is disturbed there is a potential for choroidal extra-cellular fluid to pass into the neuroretina and vitreous. Since the pigment epithelium overlying the defects in Bruch's membrane in patients with angioid streaks is atrophic, it may be expected that the $\mathrm{BRB}$ in these areas will be abnormal.

Vitreous fluorophotometry is a sensitive. reproducible and quantitative method of detecting abnormalities in the BRB. ${ }^{9,10}$

We undertook to study the blood-retinal barrier in a group of patients with angioid streaks, by the technique of vitreous fluorophotometry, and to comment on its application in the clinical setting.

\section{Patients and Methods}

Patients with angioid streaks were selected from the diagnostic index of our retinal photography department. Of these patients, seven agreed to take part in this study. Three of these seven were members of the same family. The opportunity was taken to examine another three members of this

Correspondence to: Mr. R. Brown, Retinal Photography Department, Manchester Royal Eye Hospital, Oxford Road, Manchester. M13 9WH.

Presented at the Annual Congress of the Ophthalmological Society of the United Kingdom, April 1988.

'From Manchester Royal Eye Hospital, Oxford Road, Manchester, M13 9WH. England.

${ }^{2}$ Birmingham and Midland Eye Hospital, Church Street, Birmingham, B3 2NS. England. 
family (see pedigree). In total therefore, ten patients were investigated.

All patients with angioid streaks in this study showed the skin changes of pseudoxanthoma elasticum. Informed written consent was obtained from all patients.

The ocular examination consisted of ; visual acuity as measured by Snellen chart, slit lamp examination of the anterior segments, direct and indirect ophthalmoscopy of the vitreous and retina, colour fundus photography, fluorescein angiography and vitreous fluorophotometry.

None of the patients had any other ocular or systemic conditions known to influence fluorophotometric measurements.

Fundal examination and fluorescein studies were performed following pupil dilataton which was achieved by the instillation of topical Tropicamide $1 \%$ and Phenylephrine $10 \%$. Vitreous fluorophotometry was performed using the Fluorotron Master $^{\mathrm{TM}}$ (Coherent, Palo Alto, California). The technique has been described in detail elsewhere ${ }^{11.12}$ and will be briefly reviewed here. Initial fluorotron scans, termed the background scans, were obtained from each eye. These background scans measure the natural fluorescence of the ocular tissues. A bolus of sodium fluorescein $(14 \mathrm{mg} / \mathrm{kg}$ body weight) was then injected intravenously. Standard fluorescein angiography was performed. Between 3 and 5 minutes post injection, a further scan termed the bolus scan was performed. The bolus scan is used in the final calculation to minimise the influence of chorioretinal fluorescence on the vitreous fluorescence measurement. A final scan,

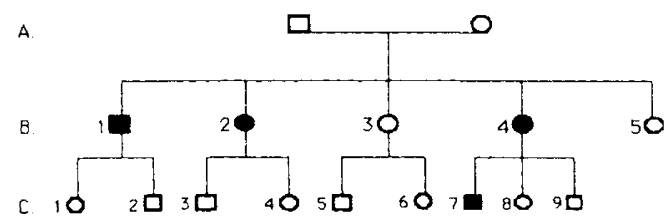

\footnotetext{
$\square=$ Male, Not Affected

$\square=$ Mole, Afrected

$\mathbf{O}=$ Female, Not Affected

= Femole, Arfected
}

Fig. 1. Pedigree of family studied with Pseudoxanthoma Elasticum. termed the measurement scan, was performed at 60 minute post fluorescein injection. Two samples of venous blood were obtained from each patient. The first taken between 5 and 10 minutes, the other at 60 minutes post injection. The exact times of the scans and the venepunctures were recorded. The plasma fluorescein values were entered into a computer algorithm to obtain the plasma fluorescein integral. A posterior vitreous penetration ratio (PR) was calculated using the scans and plasma data. ${ }^{13}$ This penetration ratio is a measurement of the integrity of the blood retinal barrier.

To establish a normal range, twenty five age and sex matched normal individuals (30 eyes) also underwent vitreous fluorophotometry according to the above method.

\section{Results}

The pedigree of the family examined is shown in Figure 1. The parents, generation A, were not examined and were reported by family members not to have any known ocular problems. No consanguinity has been known in the family.

The Table shows the examination findings of each patient. In a total of six eyes angioid streaks were present without neovascularisation or disciform scar (Fig. 2). In all these eyes the posterior vitreous penetration ratio was within normal limits. Eight eyes showed angioid streaks with subretinal neovascularisation or disciform scar (Fig. 3). In all these eyes the penetration ratio was elevated above the normal range.

The six eyes without angioid streaks all had a normal penetration ratio. The twenty five normal individuals studied had a penetration ratio of $2.35 \pm 0.76 \times 10^{-6} / \mathrm{min}$ (mean $+/-$ S.D.). This value is similar to previously published normal ranges which used the same method of analysis. ${ }^{13}$

\section{Discussion}

This study has shown that patients with uncomplicated angioid streaks and pseudoxanthoma elasticum have a normal posterior vitreous penetration ratio. To our knowledge this finding has not previously been reported. 
Table

\begin{tabular}{|c|c|c|c|c|c|c|}
\hline Patient & Sex & Age & Eye & $V / A$ & Ophthalmoscopy/FFA & $\begin{array}{l}\text { P. Ratio } \\
\times 10^{-6} / \mathrm{min}\end{array}$ \\
\hline B1 & M & 38 & $\begin{array}{l}\mathrm{R}: \\
\mathrm{L}:\end{array}$ & $\begin{array}{l}\mathrm{CF} \\
\mathrm{CF}\end{array}$ & $\begin{array}{l}\text { Extensive angioid streaks } \\
\text { and bilateral macular } \\
\text { disciform degeneration. }\end{array}$ & $\begin{array}{l}23.743 \\
17.628\end{array}$ \\
\hline B2 & $\mathrm{F}$ & 37 & $\begin{array}{l}\text { R: } \\
\text { L: }\end{array}$ & $\begin{array}{l}6 / 24 \\
6 / 6\end{array}$ & $\begin{array}{l}\text { Angioid streaks and macular } \\
\text { disciform scar } \\
\text { Angioid streaks and peripheral } \\
\text { pigmentary disturbance. }\end{array}$ & 1.619 \\
\hline B3 & $\mathrm{F}$ & 36 & $\begin{array}{l}\mathrm{R}: \\
\mathrm{L}:\end{array}$ & $\begin{array}{l}6 / 6 \\
6 / 6\end{array}$ & $\begin{array}{l}\text { Normal. No angioid streaks } \\
\text { Normal }\end{array}$ & $\begin{array}{l}1.539 \\
1.148\end{array}$ \\
\hline B4 & $\mathrm{F}$ & 34 & $\begin{array}{l}\mathrm{R}: \\
\mathrm{L}:\end{array}$ & $\begin{array}{l}6 / 5 \\
6 / 9\end{array}$ & $\begin{array}{l}\text { Angioid streaks } \\
\text { Extensive angioid streaks }\end{array}$ & $\begin{array}{l}2.789 \\
2.627\end{array}$ \\
\hline B5 & $\mathrm{F}$ & 27 & $\begin{array}{l}\mathrm{R}: \\
\mathrm{L}:\end{array}$ & $\begin{array}{l}6 / 6 \\
6 / 6\end{array}$ & $\begin{array}{l}\text { Normal. No angioid streaks } \\
\text { Normal }\end{array}$ & $\begin{array}{l}2.538 \\
1.629\end{array}$ \\
\hline $\mathrm{C} 7$ & M & 14 & $\begin{array}{l}\mathrm{R}: \\
\mathrm{L}:\end{array}$ & $\begin{array}{l}6 / 5 \\
6 / 5\end{array}$ & $\begin{array}{l}\text { Normal. No angioid streaks } \\
\text { Normal }\end{array}$ & $\begin{array}{l}1.971 \\
1.863\end{array}$ \\
\hline 1 & $\mathrm{~F}$ & 28 & $\begin{array}{l}\text { R: } \\
\text { L: }\end{array}$ & $\begin{array}{l}1 / 60 \\
6 / 6\end{array}$ & $\begin{array}{l}\text { Angioid streaks and macular } \\
\text { disciform degeneration } \\
\text { Angioid streaks }\end{array}$ & $\begin{array}{l}7.514 \\
1.711\end{array}$ \\
\hline 2 & M & 49 & $\begin{array}{l}\mathrm{R}: \\
\mathrm{L}:\end{array}$ & $\begin{array}{c}6 / 36 \\
\mathrm{CF}\end{array}$ & $\begin{array}{l}\text { Bilateral angioid streaks and } \\
\text { macular disciform scars }\end{array}$ & $\begin{array}{l}4.617 \\
6.754\end{array}$ \\
\hline 3 & M & 45 & $\begin{array}{l}\mathrm{R}: \\
\mathrm{L}:\end{array}$ & $\begin{array}{l}6 / 5 \\
6 / 5\end{array}$ & $\begin{array}{l}\text { Angioid streaks } \\
\text { Angioid streaks }\end{array}$ & $\begin{array}{l}1.940 \\
1.808\end{array}$ \\
\hline 4 & $\mathrm{~F}$ & 52 & $\mathrm{R}:$ & $6 / 6$ & $\begin{array}{l}\text { Bilateral angioid streaks with } \\
\text { marked macular pigmentary } \\
\text { disturbance amd peripheral } \\
\text { SRNV. }\end{array}$ & 10.967 \\
\hline
\end{tabular}

Patients B1 to C7 were all members of the family investigated. (see Pedigree). The other patients examined are numbered 1 to 4.

$\mathrm{V} / \mathrm{A}=$ Visual Acuity as measured by Snellen chart.

$C F=$ Count fingers at 1 metre.

$F F A=$ Fundus fluorescein angiogram.

P. Ratio $=$ Penetration Ratio (Normal range $\left.=2.35 \pm 0.76 \times 10^{-6} / \mathrm{min}\right)$

$S R N V=$ Subretinal neovascularisation.

The blood-retinal barrier therefore appears to be functionally intact in these patients despite the presence of breaks in Bruch's membrane and accompanying atrophy of the adjacent pigment epithelium. This finding is surprising since the pigment epithelium is regarded as forming part of the blood-retinal barrier. The normal members of the family studied also had penetration ratios within the normal range.

In those patients with associated disciform degeneration however, the blood-retinal barrier is markedly abnormal in all cases. This reflects the disturbance in the $\mathrm{BRB}$ that 


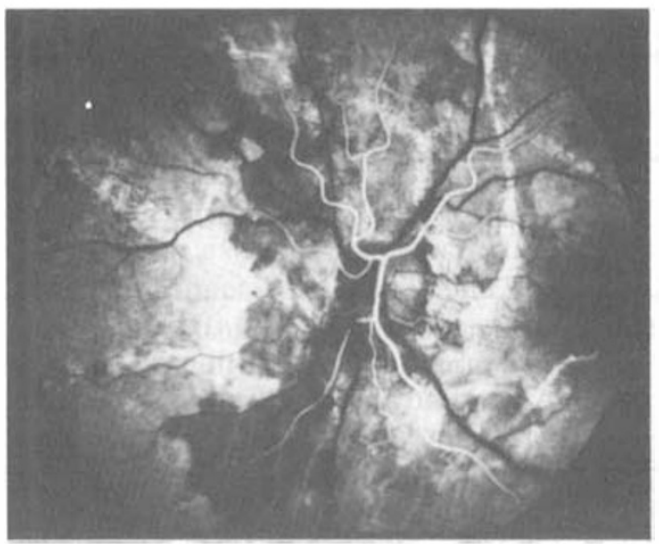

Fig. 2: Patient B4. Left Eye. Fluorescein angiogram, arterial phase. Showing hyperfluorescence of the angioid streaks.

occurs when subretinal new vessels are present. A similar breakdown of the BRB has been shown previously by a study in which four patients with age related macular degeneration and subretinal neovascularisation all had elevated penetration ratios. ${ }^{14}$ Sub-retinal neovascularisation, occurring in patients with angioid streaks, often affects the macular area, resulting in a severe loss of form vision. The results of treatment are often disappointing. Early treatment may potentially improve the visual prognosis, although early subretinal neovascularisation in association with an angioid streak may be difficult to detect. Fluorescein angiography may not be helpful as new vessel hyperfluorescence may be superimposed over the pigment epithelial defect.

In conclusion, breakdown of the BRB can be demonstrated by vitreous fluorophotometry, and as it appears that this breakdown occurs with angioid streaks only when subretinal new vessels are present, it may be possible to use vitreous fluorophotometry to identify those patients developing new vessels at an early and potentially treatable stage.

\section{References}

1 Shields JA, Federman JL, Tomer TL, Annesley WH: Angioid streaks 1. Ophthalmoscopic variations and diagnostic problems. $\mathrm{Br} J$ Ophthalmol 1975; 59: 257-66.

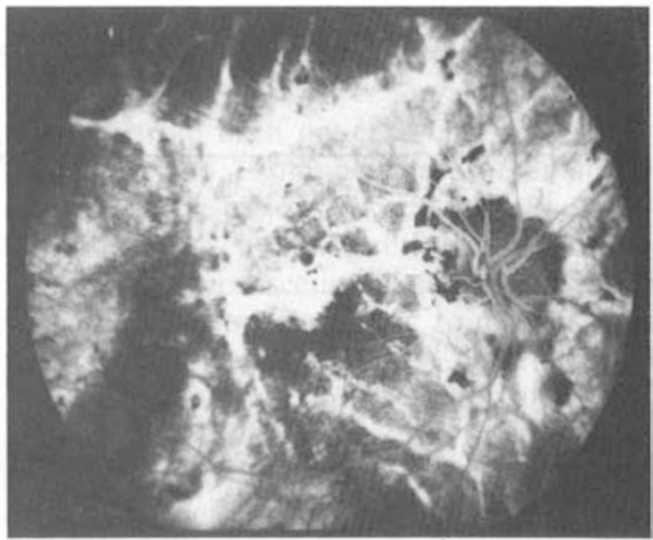

Fig. 3. Patient B2. Right Eye. Fluorescein angiogram, late phase. Showing hyperfluorescence of the angioid streaks and extensive disciform scarring.

${ }^{2}$ Hogan JF, Heaton CL: Angioid streaks and systemic disease. Br J Dermatol 1973; 89: 41116.

${ }^{3}$ Shilling JS, Blach RK: Prognosis and therapy of angioid streaks. Trans Ophthalmol Soc UK 1975; 95: 301-6.

${ }^{4}$ Hilton GF: Late serosanguineous detachment of the macula after traumatic choroidal rupture. Am J Ophthalmol 1975; 79: 997-.

${ }^{5}$ Hagedoorn A: Angioid streaks and traumatic ruptures of Bruchs membrane. Br J Ophthalmol 1975; 59: 267-.

${ }^{6}$ Green WR: Pathology of angioid streaks. In Spencer WH ed.: Ophthalmic Pathology. An atlas and textbook. Philadelphia: WB Saunders. 1985: Vol 2: 1023-1032.

${ }^{7}$ Shiose Y: Electron Microscope Studies on Blood Retinal and Blood Aqueous Barriers. Jpn J Ophthalmol 1970; 14: 73-.

${ }^{8}$ Shakib M, Cunha-Vaz JG: Studies on the Permeability of the Blood Retinal Barrier.IV. Junctional Complexes of the Retinal Vessels and their role in the Permeability of the Blood Retinal Barrier. Exp Eye Res 1966, 5: 229-.

${ }^{9}$ Cunha-Vaz JG, Faria De Abreu JR, Campos AJ et al: Early Breakdown of the Blood Retinal Barrier in Diabetes. $\mathrm{Br} J$ Ophthalmol 1975; 59: 649-56.

10) Waltman SR, Oestrich CA, Krupin T, Hanish S, Ratzan S, Santiago J, Kilo C: Quantitative Vitreous Fluorophometry. A Sensitive Technique for Measuring Early Breakdown of the Blood Retinal Barrier in Young Diabetic Patients. Diabetes 1978; 27: 85-.

11 Zeimer RC, Blair NP, Cunha-Vaz JG: Vitreous Fluorophotometry for Clinical Research. 1. 
Description and Evaluation of a new Fluorophometer. Arch Ophthalmol 1983; 101: 1753-6.

12 Zeimer RC, Blair NP, Cunha-Vaz JG: Vitreous Fluorophotometry for Clinical Research. 11. Method of Data Acquisition and Processing. Arch Ophthalmol 1983; 101: 1757-61.

13 Cunha-Vaz JG, Gray JR, Zeimer RC, Mota
MC, Ishimota BM, Leite E: Characterization of the Early Stages of Diabetic Retinopathy by Vitreous Fluorophotometry. Diabetes 1985; 34: 53-9.

${ }^{14}$ Merin S, Blair NP, Tso MOM: Vitreous Fluorophotometry in Patients with Senile Macular Degeneration. Invest Ophthalmol Vis Sci 1987; 28: 756-9. 